\title{
人工心肺操作時の精神的作業負荷の評価に関する研究 一䝪血レレベルが精神的作業負荷に及ぼす影響—
}

\author{
工藤剛実 ${ }^{1)} \cdot$ 植木章三 ${ }^{2)}$
}

\section{要旨}

人工心肺シミュレータ実験において、静脈貯血槽の貯血レベルを高 $(1,000 \mathrm{~mL})$ ・中 $(500 \mathrm{~mL})$ ・低 $(200 \mathrm{~mL})$ の 3 段階に設定し、貯血レベルが操作者の精神的作業負荷に及ぼす影響について検討した。被験者は臨床工学技士学 生 6 名とし、精神的作業負荷は生理的指標㧍よび行動的指標、主観的指標を用いて評価した。

結果として、生理的指標である $\mathrm{RR}$ 間隔変動係数と区間平均心拍数、唾液アミラーゼと、行動的指標である反応 時間には有意な変化はみられなかった。主観的指標である日本語版 NASA-TLXでは、貯血レベルが低くなると加 重平均作業負荷得点と全体的な負荷得点が有意に増加した。また、簡易精神疲労尺度においても、貯血レベルが低 くなると精神疲労と全体的疲労感の得点が有意に増加した。

これらのことから、貯血レベルが低いほど、精神的作業負荷と精神疲労、全体的疲労感が高くなることが示唆さ れた。貯血レベルの設定には、操作者の精神的作業負荷の側面からも検討が必要である。

索引用語：人工心肺、精神的作業負荷、精神的負荷、精神的負担、精神疲労

\section{A study on the mental workload evaluation of cardiopulmonary bypass operation \\ -Effects on the mental workload of reservoir level-}

Takemi Kudo ${ }^{1)}$, Shouzoh Ueki ${ }^{2)}$

Abstract : In this cardiopulmonary bypass simulation experiment, the venous blood reservoir level was classified into high $(1,000 \mathrm{~mL})$, medium $(500 \mathrm{~mL})$, and low $(200 \mathrm{~mL})$, and its influences on operators' mental workload were examined, involving 6 clinical engineering students and using physiological, behavioral, and subjective indices.

No significant changes were observed in the coefficient of variation of R-R intervals, mean heart rate, or salivary amylase as physiological indices, or reaction time as a behavioral index. On the other hand, the mean weighted workload scores of the Japanese-version NASA-TLX as a subjective index significantly increased with a decrease in the reservoir level. Similarly, the mental and overall fatigue scores of the Brief Fatigue Inventory significantly increased with such a decrease.

Based on these results, decreased reservoir levels may be associated with an increase in the mental workload, as well as mental and general fatigue levels, and, therefore, it may be necessary to consider operators' mental workload when setting the reservoir level.

Key words : cardiopulmonary bypass, mental workload, mental stress, mental strain, mental fatigue

\section{I. 緒}

2002 年に実施された「人工心肺のリスクに関する国

1) 東北文化学園専門学校 臨床工学科

工藤剛実 (Takemi Kudo)

于 981-8552 宮城県仙台市青葉区国見 6-45-16

Department of Clinical Engineer, Tohoku Bunka Gakuen

College

6-45-16, Kunimi, Aoba-ku, Sendai, Miyagi, 981-8552, Japan

2) 東北文化学園大学大学院 健康社会システム研究科

[原稿受領日：2013 年 9 月 11 日 採択日：2013 年 11 月 6 日] 内アンケート調查」1)において、人工心肺使用手術 119 例に 1 回の比率で、インシデントやアクシデントが発 生していたことが報告された。また、空気誤送が 2 年 間で56 件も発生しており、因果関係は不詳であるが 9 名の患者が死亡していた。この空気誤送の発生原因 は「目を離した」や「気を取られた」と報告されてお り、操作者に起因するヒューマンエラーが原因となっ ていた。 
この空気誤送を予防するには、静脈貯血槽（貯血槽） へのレベルセンサー設置とレベルセンサーによる送血 ポンプの制御や、送血回路への気泡検出器の設置と気 泡検出器による送血ポンプの制御が必要である。日本 体外循環技術医学会では、これらの安全装置設置状況

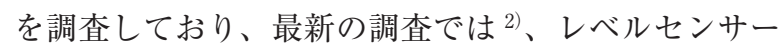
によるポンプ制御については 4 割の施設で、気泡検出 器によるポンプ制御については 3 割の施設で行われて いないことが報告されており、医療安全の側面から問 題がある。

一方で、同種血輸血量の削減や、組織浮腫の低減を 期待して人工心肺回路の短縮と細径化や、初期充填量 を削減し貯血槽の貯血レベルを最低とする人工心肺操 作が行われている。貯血レベルが低いと、空気誤送に 対する時間的余裕が少なくなり、ヒューマンエラーの 危険性が増加することが考えられる。これらの人工心 肺操作について、希釈率や出血量、同種血輸血量など の側面 ${ }^{3,4)}$ や、䝪血槽の除泡能力などの側面 ${ }^{5,6}$ ) から 検討された論文や発表はあるが、精神的作業負荷の側 面から検討された論文はない。

人工心肺の操作は、体を動かすという身体的要素よ りも、一定の姿勢で時々刻々変化する状況を監視・判 断し、操作するという精神的要素が強い。インシデン トやアクシデントが生じた場合、患者に及ぼす影響も 大きく、精神的作業負荷が高い作業である。この精神 的作業負荷が高くなり、個人の臨界值を超えるとヒュ ーマンエラーに結びっくことが考えられ、これらの関 係性を解明することは喫緊の課題である。

そこで本研究では、貯血槽の貯血レベルを高 $(1,000 \mathrm{~mL})$. 中 $(500 \mathrm{~mL})$ ・低 $(200 \mathrm{~mL})$ の 3 段階に設定し、貯血 レベルが低いほど、精神的作業負荷が高くなるかを明 らかにするため、臨床工学技士学生を操作者とした人 工心肺シミュレータ実験を行った。

本研究では、JIS Z8502「人間工学一精神的作業負荷 に関する原則一」 ${ }^{7)}$ に従い、外部から作用を及ほすす「負 荷」と、負荷によって生じる効果を「負担」として、 用語を使い分けるとともに、両者の内容を含む場合は、 メンタルワークロードの日本語訳である「精神的作業 負荷」を使用する。

なお、開示すべき産学連携利益相反はない。

\section{II. 研 究方法}

\section{1. 被験者}

本研究では、東北文化学園専門学校臨床工学科 3 年 に在籍し、書面によるインフォームド・コンセントに 同意を得た若年男性 6 名を被験者とした。被験者は、 年齢 21 歳 (実験時)、身長 $175.0 \pm 9.0 \mathrm{~cm}$ 、体重 $66.5 \pm$ $8.6 \mathrm{~kg}$ 、腕長 $76.2 \pm 4.6 \mathrm{~cm}$ であり、全員が右利きであった。
また全員が人工心肺のシミュレータ実験を経験し、人 工心肺の操作方法に一定の知見を得ていた。

\section{2. 実験装置および実験室}

今回の実験では、日本心臟血管外科学会ら 4 学会と 日本医療器材工業会が取りまとめた「人工心肺装置の 標準的接続方法掞よびそれに応じた安全教育等に関す るガイドライン」8)で採用された標準的回路を参考に、 人工心肺にはマッケ・ゲティンゲ社製ヨストラ人工心 肺 HL20 を、貯血槽と一体型人工肺にはテルモ社製キ ヤピオクス ${ }^{\circledR} \mathrm{RX}(\mathrm{CX}-\mathrm{RX} 25 \mathrm{R})$ を用い、人体を模擬す る貯血バック（貯血量 3,000mL）により実験装置を作 製した。送血ポンプにはローラポンプを用いて目標流 量を $3.5 \mathrm{~L} / \mathrm{min}$ (成人男性平均 $\mathrm{BSA}: 1.7 \mathrm{~m}^{2}$ 、灌流量を $2.1 \mathrm{~L} / \mathrm{min} / \mathrm{m}^{2}$ として算出）に設定した。脱血量は回路 チューブを銈子で挟み、この鉗子の開閉で調整した。

実験室は長方形状（横 $3.2 \mathrm{~m} \times$ 奥行 $9.4 \mathrm{~m} \times$ 高さ $2.5 \mathrm{~m}$ ) であり、空調にて室温 $25.0^{\circ} \mathrm{C}$ に維持した。実験は連続 する 3 日間で行われ、同一時間带、同一環境条件下で 行うように設定した。

\section{3. 貯血レベルの設定}

操作者に加える精神的負荷として、貯血槽の貯血レ ベルを 3 段階に設定した。貯血槽監視は人工心肺操作 の中心的業務であり、䝪血レベルが低いほど、空気誤 送への時間的余裕が少なくなることから、精神的負荷 として操作者に影響を及ぼすと考えた。

低貯血レベル（低レベル）は、貯血槽（CX-RX25R） の最低䝪血レベルである $200 \mathrm{~mL}$ とし、中貯血レベル (中レベル) を $500 \mathrm{~mL} 、$ 高䝪血レベル（高レベル）を $1,000 \mathrm{~mL}$ とそれぞれ設定し、操作中は設定した貯血レ ベルを維持してもらった。中レベルの設定において、 東北地区に扔いて開心術を行っている 10 施設の臨床 工学技士に対して聞き取りを行い、体外循環開始時の 貯血レベルの平均值 $(480 \pm 194 \mathrm{~mL})$ から $500 \mathrm{~mL}$ に設 定した。高レベルは、便宜上、中レベルの 2 倍とした。

\section{4. 操作プロトコル}

本研究では、時間経過によって生じる二次的な精神 的負担の影響を少なくするため、人工心肺の操作時間

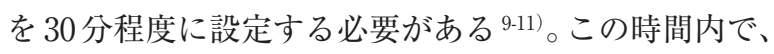
臨床と同様の人工心肺操作手技を再現するため、「心 臓手術の実際 (人工心肺操作)」12) を参考に、開始から 終了までを操作開始、大動脈遮断、 $\mathrm{CP}$ 注入 1 - 冷却開 始、維持期 (反応時間 1 )、維持期 (無操作)、維持期 (反 応時間 2)、CP 注入 2 、維持期（反応時間 3)、復温開始、 大動脈遮断解除、離脱操作開始、送血流量減少、操作 終了の 13 の操作イベントとし、1つのイベントをシミ ユレータ実験で再現が可能な 3 分（操作時間計 36 分） として共通の教示を与えて操作してもらった。 


\section{5. 評価指標}

精神的作業負荷の評価法については、古くから多く の方法が提案されているが、大別して「生理的指標」と 「行動的指標」「主観的指標」が用いられている ${ }^{9-11,13)}$ 。 本研究では、先行研究 ${ }^{10,11)}$ を参考に、本施設で検証可 能な 3 種類 6 項目の指標を適用した。

\section{1）生理的指標}

生理的指標には「心拍変動」拈よび「唾液アミラー ゼ」を用いた。

心拍変動は、被験者に加わる精神的負荷によって、 心臓交感神経活動と心臟副交感神経活動のバランスの 変化により、心臟電気活動が変化することを利用して 精神的作業負荷を評価する指標である ${ }^{14-16)}$ 。本研究で は、心電図モニ夕（日本光電社製 Life Scope8）で胸 部 $\mathrm{CM}_{5}$ 誘導にて導出した心電図信号を、 $\mathrm{AD}$ 変換器 (BIOPAC Systems,inc. MP100A) でPCに取り込み、 解析ソフト (BIOPAC Systems,inc. Acqknowledge ${ }^{\circledR}$ ver3.9）で測定 windowを 180 秒とした心電図信号か ら $\mathrm{RR}$ 間隔を求め、 $\mathrm{RR}$ 間隔変動係数 $\left(\mathrm{CV}_{\mathrm{R}-\mathrm{R}}\right)$ と区間 平均心拍数（HR）を算出した。得られた值は、その 測定 window 中央の時刻データとした。

唾液アミラーゼは、ストレスによる交感神経系の興 奮により唾液アミラーゼが活性化されることを利用し

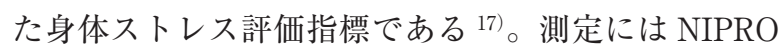
社製ストレス測定器 COCORO METER を使用し、測 定用チップは舌下に入れ 30 秒間保持し、直後に測定 を行った。

\section{2）行動的指標}

行動的指標には「二重課題法」である「反応時間」 を用いた。

二重課題法は、主課題作業で消費されているリソー スが大きいほど、副次課題に割くリソースが低下し、 副次課題のパフォーマンスが低下することから、精神 的作業負荷を評価する指標である ${ }^{18)}$ 。本研究では、警 報鳴動から警報復帰までの反応時間を測定するモック （縦 $6.5 \mathrm{~cm} \times$ 横 $10.0 \mathrm{~cm}$ ）を作製し、人工心肺に設置した。 研究者側のスイッチを入れると警報が鳴動し、同時に 電圧が出力される。操作者が警報に気がつき、警報復 帰ボタンを押すと警報が途切れ電圧が 0 となる。この 電圧を $\mathrm{AD}$ 変換器 $(\mathrm{MP} 100 \mathrm{~A})$ にて PC に入力し、解析 ソフト (BIOPAC Systems,inc. Acqknowledge ${ }^{\circledR}$ ver3.9) にて反応時間を求めた。

\section{3）主観的指標}

主観的指標には「日本語版 NASA-TLX」および「簡 易精神疲労尺度」を用いた。

NASA-TLX は ${ }^{19)}$ 、米国航空宇宙局で開発された精 神的作業負荷を評価する指標で、「知的・知覚的要求」 や「身体的要求」「多ムプレシャー」「作業成績」、
「努力」「フラストレーション」の 6 つの下位尺度と、 下位尺度を一対比較法によって重み付けして算出する 「加重平均作業負荷得点（WWL）」の 7 項目からなる。 各下位尺度は Visual Analogue Scaleによって0〜100 点の得点に換算され、得点が高いほど「大きい」や「強 い」「悪い」「多い」を表す。この得点に、重み付け 順に $5 \sim 0$ の係数を掛け、平均化してWWL 得点を算 出する。本研究では、尺度に「全体的な負荷」を追加し た「日本語版 NASA-TLX」の尺度名と説明文を用い、下 位尺度の重み付けにカードソート法を利用した「CSTLX」 を用いた ${ }^{20)}$ 。CSTLX は、カード表面に記載された 6 項目の下位尺度を重要度の順に並べ、6〜1の重み付 けを行い下位尺度の得点とかけ合わせ、 6 項目の総和 を重み付け係数の総和である 21 で割ることによって WWL を求める方法である。

「精神疲労尺度」は、JIS Z8502 ${ }^{7}$ )に基づき精神的負 担の減退的効果を問う合計 20 項目からなる指標であ り、本研究では記入時間の短縮を目的に開発され「精 神疲労」と「単調感」「注意力の低下」、「心的飽和」、 「全体的疲労感」の 5 つの尺度から構成された「簡易

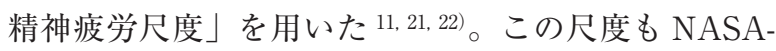
TLX と同様に、Visual Analogue Scale によって0〜 100 点の得点に換算され、得点が高いほど「大きい」や「強 い」「悪い」、「多い」を表す。

\section{6. 実験プロトコル}

被験者が実験室入室後、環境に慣れるため 10 分間 の順応時間を取った。順応時間冒頭に口腥内を洗浄す る目的で、100mL の蒸留水にてうがいを行い、心電図 モニ夕の電極を脱脂処置後に装着し、着座後に心電図 の記録を開始した。心電図測定に際して、被験者には 着座姿勢のままで普通の呼吸法を求めたが、呼吸統制 は行わなかった。順応時間に引き続き、実験を開始し た。着座姿勢のまま 10 分間の安静時間をはさみ、操 作プロトコルに従い、操作を開始した。操作終了後は、 着座姿勢のまま 10 分間の安静時間と 10 分間の休慜時 間を取り、一連のシミュレータ実験を終了した。

生理的指標である $\mathrm{CV}_{\mathrm{R}-\mathrm{R}}$ と HR の解析にあたって、 操作開始 5 分前の值を「HRV-操作前」とし、操作終 了 1 分 30 秒前を「HRV-操作終了直前」、操作終了 8 分 30 秒後を「HRV-操作後」とした。「HRV-操作終 了直前」について操作終了直後の值を用いなかったの は、 $\mathrm{CV}_{\text {R-R }}$ や HR 測定では、180 秒の window 中央を その時刻デー夕とするため、操作直後の值には、唾液 採取や主観的指標の記載時点の成分も含まれるからで ある。「HRV-操作後」についても同様に、他の指標と の競合を避けるため、8 分 30 秒後の值を用いた。

唾液アミラーゼの測定は実験中の 3 時点とし、実験 開始 3 分後を「SA-操作前」とし、操作終了直後を「SA 


\begin{tabular}{|c|c|c|c|}
\hline 時間経過 & Pump Event & ECG & 測定項目 \\
\hline $0-$ & 順応時間 & $\Delta$ & \\
\hline $10-$ & 実験開始 & & \\
\hline $13-$ & 唾液採取 & & SA-操作前 \\
\hline $15-$ & & & HRV-操作前 \\
\hline $20-$ & 操作開始 & & \\
\hline $23-$ & 大動脈遮断 & & \\
\hline $26-$ & $\mathrm{CP}$ 注入 1 - 冷却開始 & & \\
\hline $29-$ & 維持期（反応時間 1） & & 反応時間 1 \\
\hline $32-$ & 維持期（無操作） & & \\
\hline $35-$ & 維持期（反応時間 2） & & 反応時間 2 \\
\hline $38-$ & CP 注入 2 & & \\
\hline $41-$ & 維持期（反応時間 3） & & 反応時間 3 \\
\hline $44-$ & 復温開始 & & \\
\hline $47-$ & 大動脈遮断解除 & & \\
\hline $50-$ & 離脱操作開始 & & \\
\hline $53-$ & 送血流量減少 & & HRV-操作終了直前 \\
\hline \multirow[t]{4}{*}{$56-$} & 操作終了 & & \\
\hline & 唾液採取 & & SA-操作終了直後 \\
\hline & & & 精神疲労尺度 \\
\hline & & & 日本語版 NASA-TLX \\
\hline $64-$ & & & HRV-操作後 \\
\hline $66-$ & 唾液採取 & & $\begin{array}{c}\text { SA-操作後 } \\
\text { カードソート }\end{array}$ \\
\hline $76-$ & 実験終了 & $\mathbf{\nabla}$ & \\
\hline
\end{tabular}

図 1 実験プロトコル

-操作終了直後」、操作終了 10 分後を「SA-操作後」と した。

反応時間の測定は、操作イベントの「維持期（反応 時間)」に 3 回測定した。実験に先立ち、被験者には「操 作中に警報が鳴動した場合、警報復帰ボタンを押すこ と」と教示を行い、各測定の予告は行わなかった。反 応時間の統計解析にあたり、反応時間の分布は非対称 分布となることから、各貯血レベルにおける 3 回の測 定值の平均を求め代表值とした ${ }^{18)}$ 。

主観的指標である日本語版 NASA-TLX と簡易精神 疲労尺度については、操作終了後の唾液アミラーゼの 測定に引き続き記入を求めた。記入にあたっては、操 作中の状態で記入するよう被験者に教示を行った。各 指標の記入には研究者が同席して被験者自身に紙筆法 により記入してもらった。操作終了 10 分後にカード ソートによる重み付けを実施し、主観的指標の測定を 終了した（図 1)。

操作の慣れによる順序効果を相殺するため、高・中・ 低の貯血レベルに対して、異なる 6 通り操作順を作成 し、6 名の被験者に抽選で割り付け、カウンタバラン スした。

\section{7. 統計解析手法}

生理的指標である $\mathrm{CV}_{\mathrm{R}-\mathrm{R}}$ と HR、唾液アミラーゼにつ
いて、貯血レベル（3 水準）と測定時点（3 時点）に ついて、繰り返しのある二元配置分散分析を行った。 更に貯血レベル別に、繰り返しのある一元配置分散分 析を行い、PLSD 法を用いて多重比較を行った。

行動的指標である反応時間については、貯血レベル (3 水準) について、繰り返しのある一元配置分散分 析を行い、PLSD 法を用いて多重比較を行った。

主観的指標である日本語版 NASA-TLX と CSTLX の重み付け係数、簡易精神疲労尺度については、貯血 レベル（3 水準）における各尺度の得点について、繰 り返しのある一元配置分散分析を行い、PLSD 法を用 いて多重比較を行った。

統計解析は SPSS 11.5J for Windowsを用いて、有意 水準 $5 \%$ 未満をもって統計的有意とした。

\section{8. 倫理的配慮}

本研究に先立ち、東北文化学園大学研究倫理審査委 員会へ被験者および研究方法、精神的作業負荷評価指 標について審査を依頼し、承認（文大倫第 10-08 号）さ れた条件の下で実験を行った。 


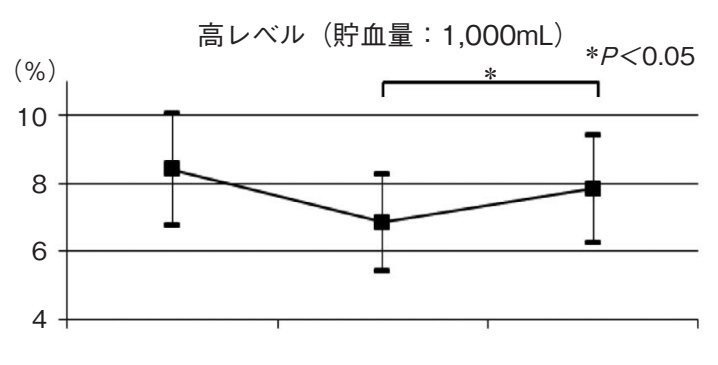

中レベル $(500 \mathrm{~mL})$

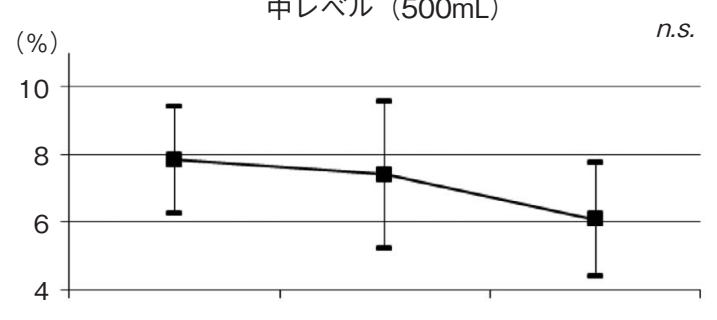

低レベル (200mL)

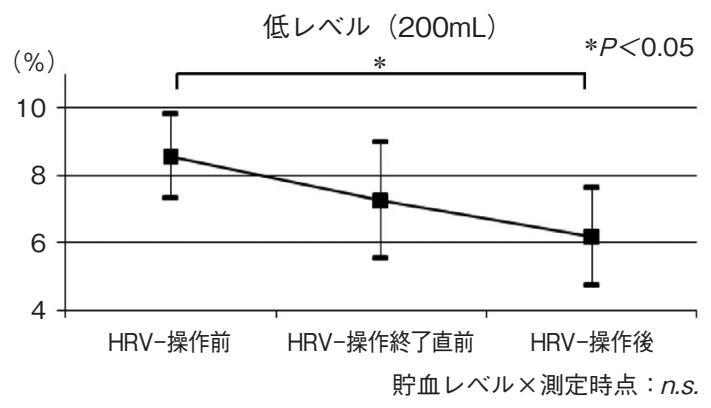

図 2a 貯血レベル別の CV $V_{R-R}$ の平均値 $(n=6)$
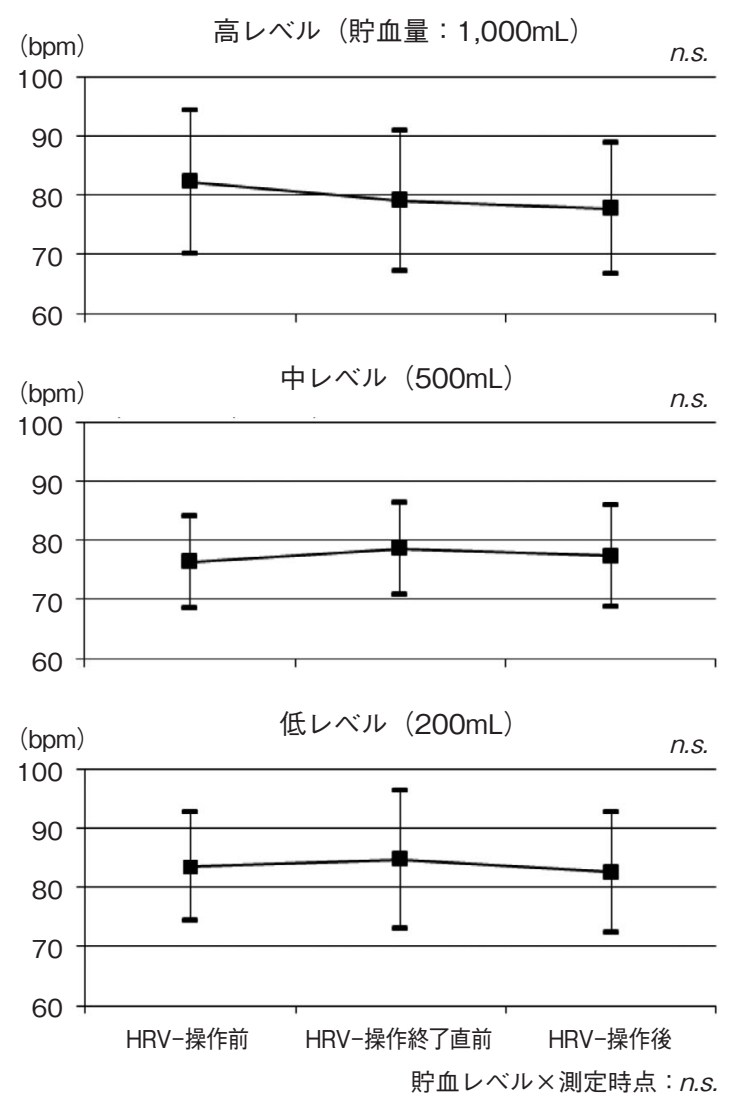

図 $2 b$ 貯血レベル別の HR の平均値 $(n=6)$

図 2 貯血レベル別の心拍変動関連指標の平均値 $(n=6)$

\section{III. 結 果}

\section{1. 生理的指標}

\section{1）心拍変動関連指標}

$\mathrm{CV}_{\mathrm{R}-\mathrm{R}}$ と HR の䝪血レベル別の平均值の推移を図 2 に 示す。CVR-R について、有意な交互作用はみられなか った。䝪血レベル別にみると、高レベルでは、操作終 了直前值よりも操作後の $\mathrm{C} V_{\mathrm{R}-\mathrm{R}}$ が有意に高くなってお り、低レベルでは、操作前と比較して操作後の $\mathrm{CV}_{\mathrm{R}-\mathrm{R}}$ が有意に低くなった。

HRについて、有意な交互作用はみられなかった。ま た貯血レベル別の多重比較においても、有意差はみら れなかった。

\section{2）唾液アミラーゼ}

唾液アミラーゼの貯血レベル別の平均值の推移を図 3 に示す。貯血レベル（3 水準）と測定時点（3 時点） について、有意な交互作用はみられなかった。貯血レ ベル別にみると、中レベルにおいて、操作終了直後と 比較して操作後のアミラーゼ值が有意に低くなった。

\section{2. 行動的指標}

反応時間の平均值を図 4 に示す。貯血レベル（3 水 準)ついて、有意差はみられなかった。
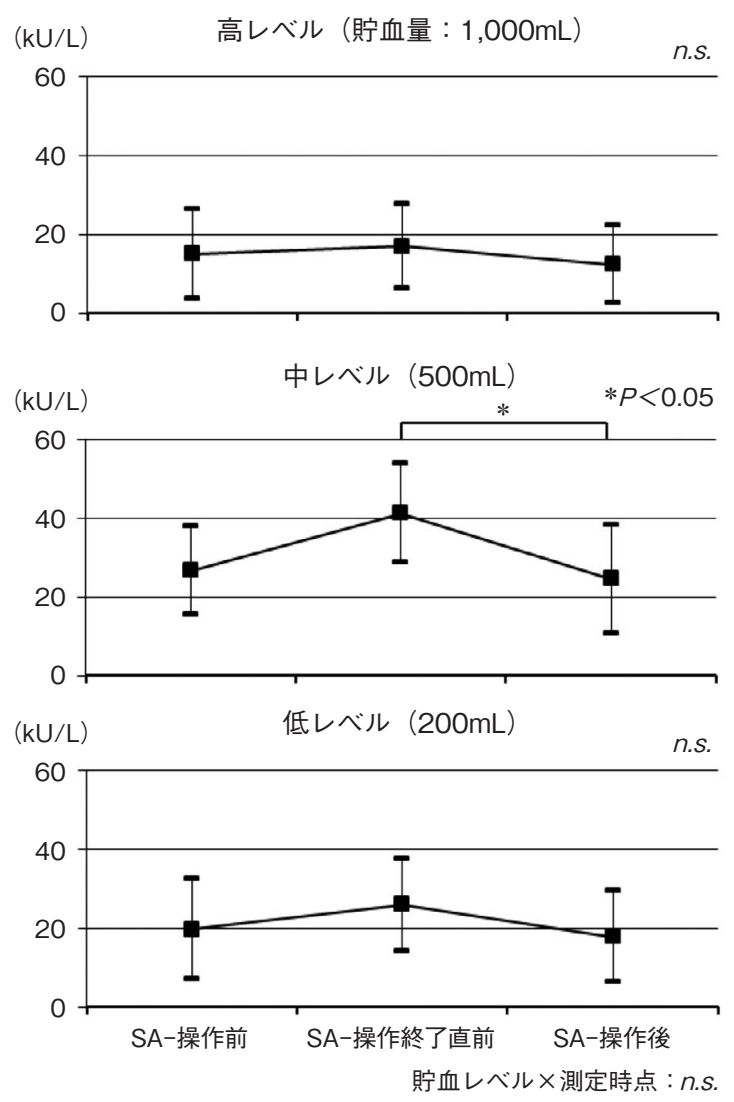

図 3 貯血レベル別の唾液アミラーゼの平均値 $(n=6)$ 


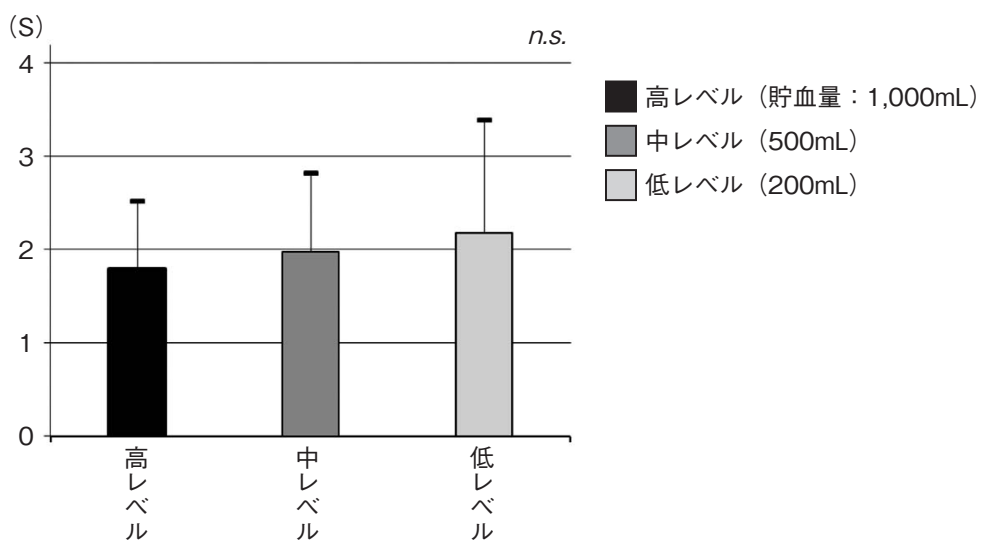

図 4 貯血レベル別の反応時間の平均値 $(n=6)$

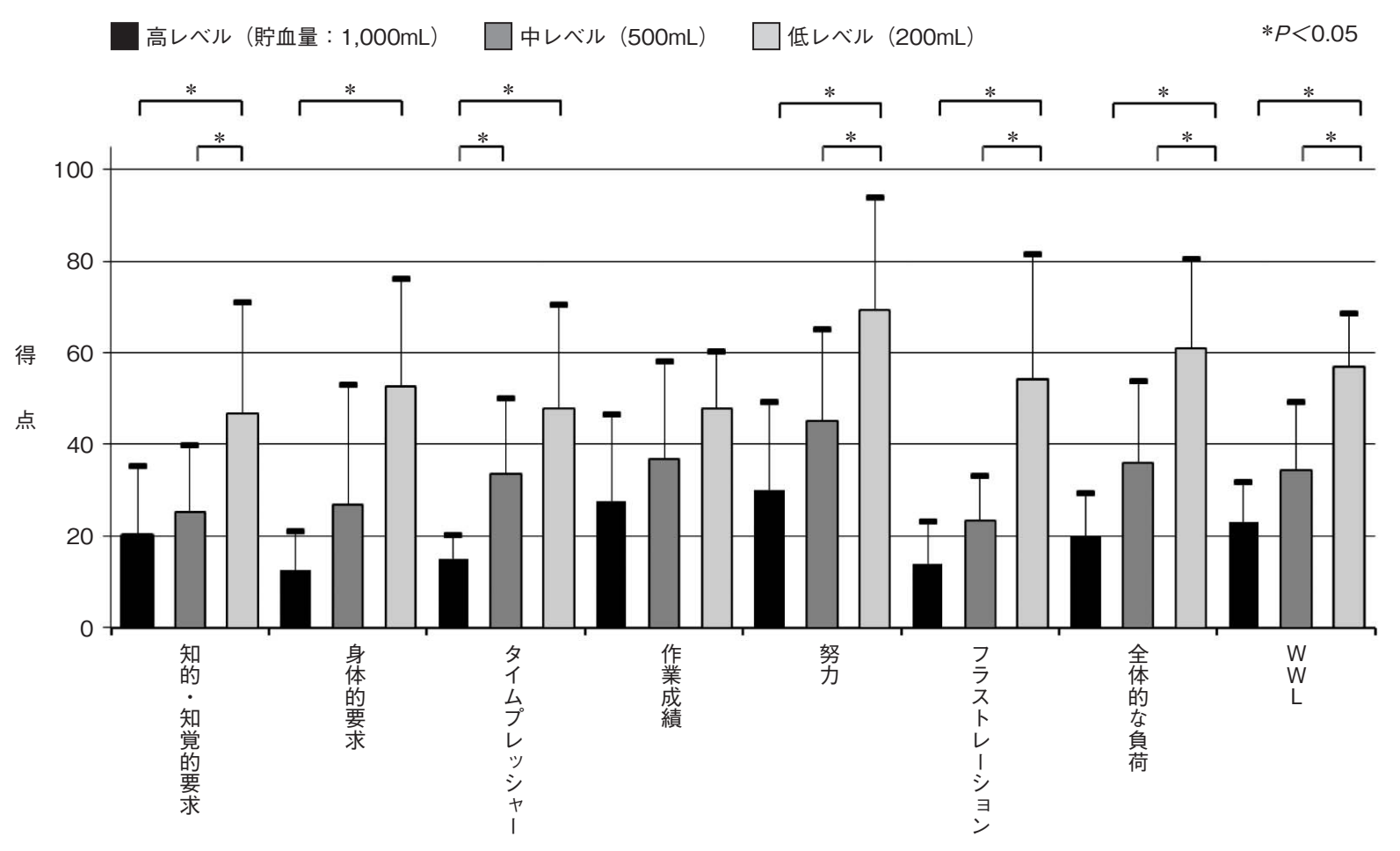

図 5 貯血レベル別の NASA-TLX 得点 $(n=6)$

\section{3. 主観的指標}

\section{1）日本語版 NASA-TLX}

日本語版 NASA-TLX の貯血レベル別の得点の推移 を図 5 に示す。下位尺度では、作業成績を除いた尺度 において、貯血レベルが低くなるのに応じて得点が高 くなっており、貯血レベルによる有意差がみられた(知 的-知覚的要求 $(p<0.01)$ 、身体的要求 $(p<0.01)$ 、夕 イムプレッシャー $(p<0.01)$ 、作業成績 $(p=0.10)$ 、努 力 $(p<0.01)$ 、フラストレーション $(p<0.01))$ 。また、 全体的な負荷 $(p<0.01)$ と WWL 得点 $(p<0.01)$ に ついても、譻血レベルが低くなるのに応じて得点が高 くなっており、眝血レベルによる有意差がみられた。

CSTLX の重み付け係数の平均值の推移を図 6 に示
す。作業成績について、貯血レベルによる有意差がみ られた（ $p<0.05 ）$ 。各尺度について貯血レベルごとに みると、知的・知覚的要求では、高レベルと比較する と中レベルの係数が有意に高くなった $(p<0.05)$ 。ま た、作業成績では、低レベルと比較すると高レベルの 係数が有意に高くなった $(p<0.05)$ 。

\section{2）簡易精神疲労尺度}

簡易精神疲労尺度の貯血レベル別の得点の推移を図 7 に示す。精神疲労 $(p<0.01)$ と全体的疲労感 $(p<$ 0.05）について、䝪血レベルが低くなるのに応じて得 点が高くなって抢り、眝血レベルによる有意差がみら れた。各尺度について䝪血レベルごとにみると、精神 疲労では高レベルおよび中レベルと比較して低レベル 
の得点が有意に高く $(p<0.05)$ 、全体的疲労感では高 レベルと比較すると低レベルの得点が有意に高くなっ た $(p<0.05)$ 。

4. その他

実験手順の順序効果による影響について再評価を行
ったところ、全ての指標について有意差はみられなか った。

高レベル（貯血量 : 1,000mL） $\square$ 中レベル $(500 \mathrm{~mL} ） \square$ 低レベル $(200 \mathrm{~mL}$ )

$* P<0.05$

係

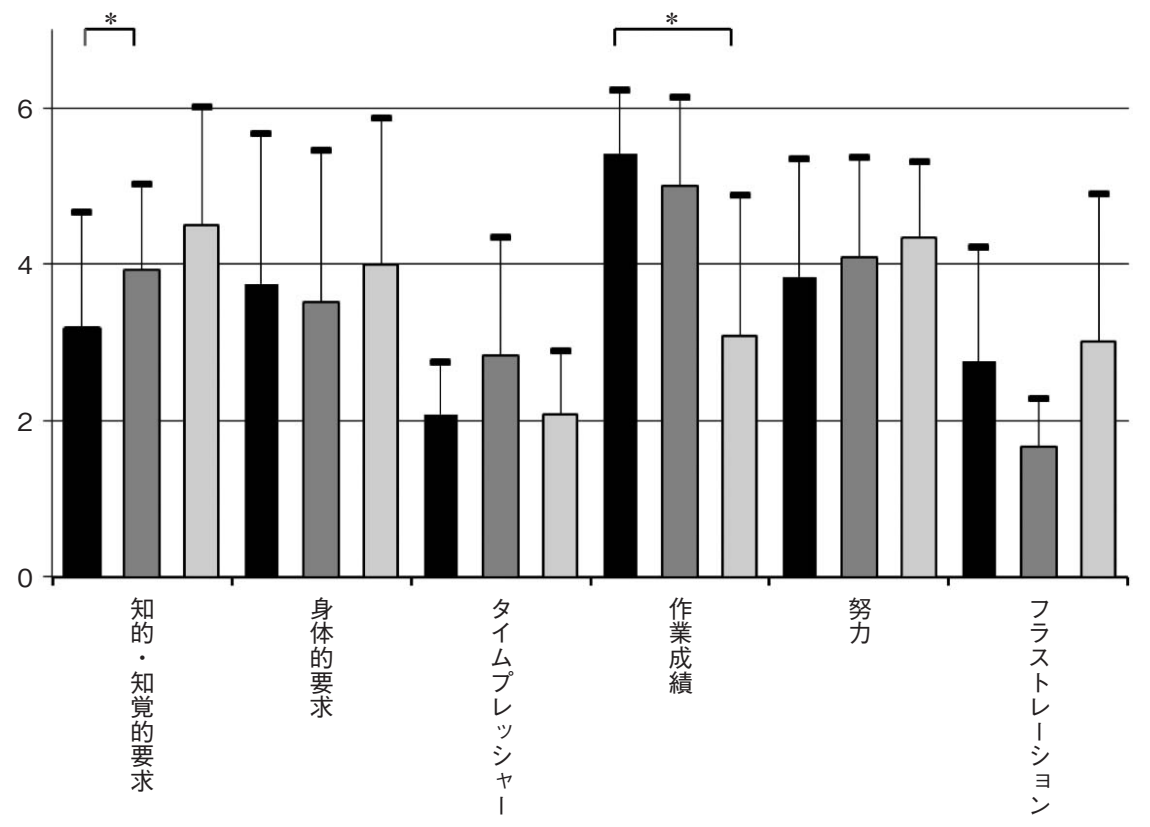

図 6 貯血レベル別の CSTLX の重み付け係数 $(n=6)$

高レベル（貯血量：1,000mL） $\square$ 中レベル (500mL) $\square$ 低レベル (200mL)

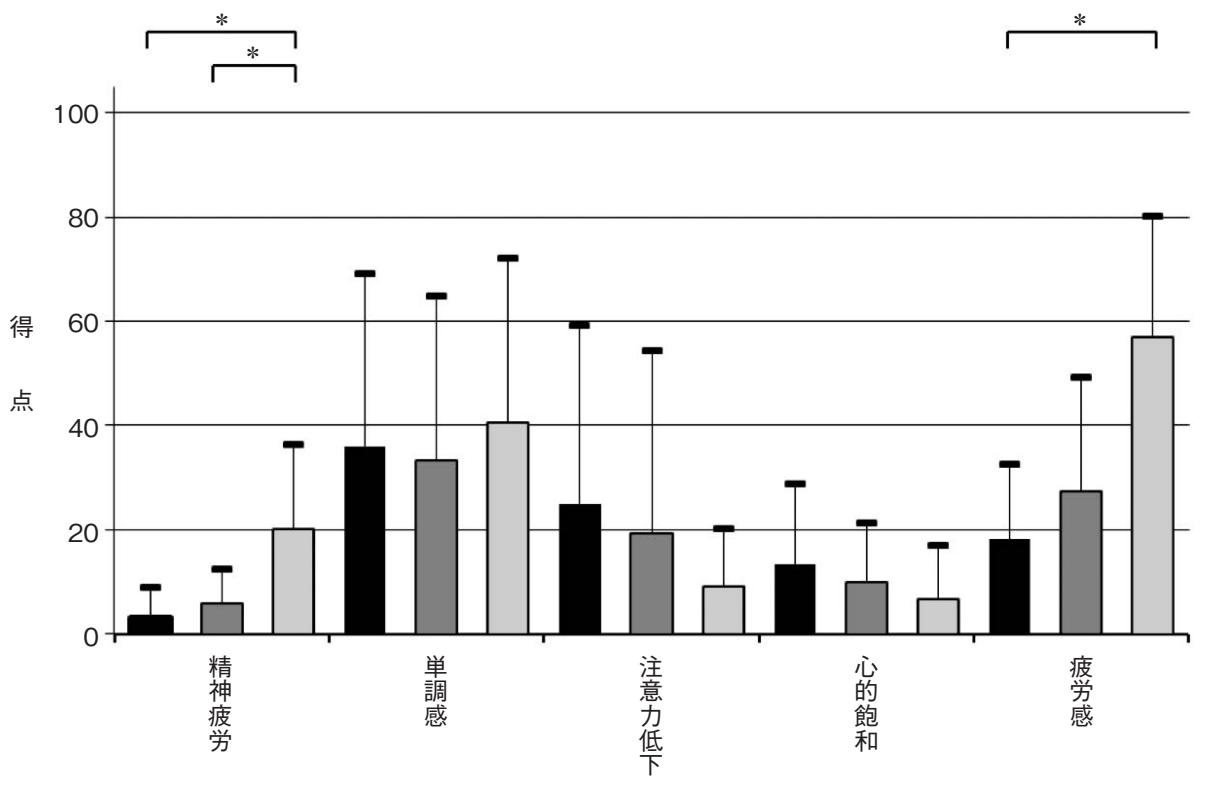

図 7 貯血レベル別の簡易精神疲労尺度得点 $(n=6)$ 


\section{IV. 考察}

本研究の結果として、譻血レベルが低いほど、精神 的作業負荷が高くなり、精神的負担の減退的効果であ る精神疲労と全体的疲労が高くなることが示唆された。 篠田らは ${ }^{10)}$ 、作業の困難度と時間的要因を分ける必要 があることを提唱しており、30 分以上に及ぶ連続作業 では、覚醒変動や気分の変動など時間的要因を含める 必要があるとしている。本研究では、人工心肺の操作 時間を 36 分に設定した同一の操作プロトコルで実施 されているため、二次的な精神的負担の影響が少なく、 譻血レベルが精神的作業負荷に及ぼす影響を分析する ことが可能と考えられる。

主観的指標である日本語版 NASA-TLX については、 貯血レベルが低くなるのに応じて、すべての下位尺度 と全体的負荷、WWLの得点が高くなっており、貯血 レベルに対して感度の良い指標であることが示唆され た。芳賀らは 20)、各種室内実験に日本語版 NASA-TLX を適応し、作業負荷の性質が異なっている状況におい ても、WWL 得点が困難度の変化に感度良く対応して いることを報告している。本研究においても WWL 得 点が貯血レベルに感度良く対応している結果となった。 しかしながら、すべての下位尺度の得点が、貯血レベ ルが低くなるのに応じて高くなっていることから、精 神的作業負荷の分析力に欠けることが考えられる。そ こでCSTLX の重み付け係数について検討したところ、 低レベルでは知的・知覚的要求の重み付け係数が高く、 中レベルと高レベルでは作業成績の重み付け係数が高 くなっていた。知的・知覚的要求の説明文は「どの程 度の知的・知覚的活動 (考える、決める、計算する、記 憶する、見るなど）を必要としましたか。課題はやさ しかったですか、難しかったですか。単純でしたか、 複雑でしたか。正確さが求められましたか、大ざっぱ でよかったですか。」であり、貯血レベルが低くなると、 リザーバの液面監視（見る）や、人工心肺の操作を考 えて決断するという知的・知覚的活動が高くなること が示唆された。

簡易精神疲労尺度については、貯血レベルが低くな るのに応じて、精神疲労と全体的疲労感が高くなるこ とが示唆された。JIS Z8502 7) によれば、精神疲労は 精神的負担の強さや、時間的パターンに依存するとさ れる。操作プロトコルを同一として時間パターンの影 響が少ない本研究では、精神的負担の影響を受け、精 神疲労が高くなったと考える。また、全体的疲労感に ついては、時間的要因によって上昇することが指摘さ れているが 11)、二次的な精神的負担の影響が少ない本 研究では、精神的負担と精神疲労に影響を受けたもの と考えることができる。一方で、状況がほとんど変化 しないために生じる「単調感」や「注意力の低下」、心
的飽和」については、貯血レベルに応じた変化がみら れなかった。二次的な精神的負担の影響が少ない実験 であることに加え、これらの 3 要因は、作業終了とと もに消失するとされており ${ }^{7)}$ 、評価が困難であったこ とが考えられる。これらのことから、貯血レベルが精 神疲労と全体的疲労感へ影響を及ぼしていることが示 唆された。

一方で、生理的指標については貯血レベルに応じた 変化がみられなかった。副交感神経の指標である $C V_{R-R}$ について、高レベルでは操作終了後に回復傾向がみら れたものの、低レベルでは回復傾向がみられなかった。 $C V_{R-R}$ は過度の緊張状態で低下することが知られてお り、低レベルでは、操作終盤に緊張状態が継続してい たことが示唆された。交感神経と副交感神経の指標で ある HR については、貯血レベルに応じた有意な変化 はみられなかった。また、交感神経活動指標である唾 液アミラーゼも、貯血レベルに応じた有意な変化はみ られなかった。心拍変動関連指標については、測定ス トレスが小さく、連続データの採取が可能であるが、 被験者の呼吸によって影響を受けることが指摘されて いる ${ }^{23)}$ 。唾液アミラーゼは、唾液採取時のストレスが 小さい（舌下に 30 秒間保持）と評価されているが 17)、 臨床において人工心肺操作中の唾液採取は、集中力の 低下を招くことが考えられ適用することができない。 生理的指標については、今後、他の指標を使用するこ とも含めて検討したい。

反応時間ついては、変化がほとんどなかった。本研 究における維持期の主課題は、リザーバや人工心肺の 監視業務が中心となり、離脱操作開始や流量減少など、 操作や監視の項目数が多い操作イベントと比較すると、 リソースの消費が少ないと考えられ、副次課題である 反応時間に十分対処でき、反応時間の変化を抽出でき なかったと考える。反応時間を維持期以外のイベント で測定することも考えたが、他の評価指標との競合を 考え見送った。本研究の副次課題として、脱血不良な ど危機対応時の作業成績を用いることも検討したが、 成績が被験者の知識量に依存することが考えられ適用 できなかった。河野は、二重課題法の不自然さを指摘 しており 24)、臨床において人工心肺操作中に副次課題 を求めることは、医療事故を防止する観点からもでき ない。行動的指標については、指標の問題点が表出す る結果となった。

本研究の限界として、実験環境が実験室であること と、被験者が学生であることがあげられる。実験室で は、実際の手術室における雲囲気や臨場感、時間的圧 迫感などの環境要因を再現することは不可能であり、 これらの要因は測定結果に影響を及ぼすことが考えら れ、「貯血レベル」という要因以外のバイアスがかか 
る可能性がある。しかしながら、実際の手術室におい て、実験的に貯血レベルを変えて精神的作業負荷を測 定する実験モデルを構築することは倫理的にも困難で あり、実験室での研究設定として実施した。一方で、 被験者は学生であり、実際の人工心肺操作を担保でき るか問題がある。しかしながら被験者は、講義や人工 心肺シミュレー夕実験などを通して、空気誤送が及ぼ す影響について、その危険性を十分認識している。実 験モデルを構築する段階で、貯血レベルが低い場合、 空気誤送の危険性が高まるという認識は、実際の操作 者だけにとどまらず学生においても共通した知識であ ると考え、学生を被験者として実施した。

本研究の結果から、貯血レベルが低くなると、精神 的作業負荷と精神疲労、全体的疲労感が高くなること が示唆された。したがって、より低い貯血レベルで安 全に操作するためには、レベルセンサーや気泡センサー と送血ポンプを連動させることで、空気誤送を防止す ることが必要である。また、操作者に精神的作業負荷 が加わらない貯血レベルの設定を検討する必要がある。

\section{V. 結 論}

1. 人工心肺操作時に貯血レベルが低くなると、操作 者の精神的作業負荷と精神疲労、全体的疲労感が 高くなることが示唆された。

2. 人工心肺操作の精神的作業負荷を感度よく反映し ていた指標は、主観的指標である日本語版 NASATLX と簡易精神疲労尺度であった。

3. 生理的指標と行動的指標について、貯血レベルの 変化に応じた反応はみられなかった。

4. 静脈貯血槽の貯血レベルの設定には、操作者の精 神的作業負荷の側面からも検討が必要である。

[謝辞］本実験にご協力いただいた臨床工学技士学生の皆様に感 謝申し上げます。

\section{参考文献}

1）古瀬 彰編: 人工心肺安全マニュアル. 初版, 東京, じほう. 2004. p117-127.

2）安全装置設置状況に関するアンケート 2012 年集計結果：体 外循環技術，40（1）；106-117，2013.

3）西田慎一, 上屋敷繁樹, 染谷忠男, ほか：低充填量人工心 肺回路による輸血量削減. 体外循環技術, 29（1）；25-28, 2002.

4）大越真紀子, 北本憲永, 小出昌秋, ほか：無輸血・無希釈 体外循環を目指して。体外循環技術，33（1）；12-15, 2006.
5）吉岡信也, 染谷忠男, 植木弘一, ほか：成人用人工心肺シ ステムの低充填化と安全性の検討．体外循環技術, 30（1）; 29-33, 2003.

6）北本憲永, 村松明日香, 小出昌秋, ほか：低充填量化が安 全性を損なわないために．体外循環技術，33（3）：292，2006.

7）日本工業規格：JIS Z8502-1994 人間工学一精神的作業負荷 に関する原則一用語及び定義，日本規格協会. 1994.

8）日本心臟血管外科学会, 日本胸部外科学会, 日本医療器材 工業会 編：人工心肺装置の標準的接続方法およびそれに応 じた安全教育等に関するガイドライン. 厚生労働省医薬品・ 医療機器等安全性情報（No.237）。 2007.

9）芳賀 繁：ワークロード，伊藤謙治，小松原明哲，ほか編. 人間工学ハンドブック．初版，東京，朝倉書店．2003。p138151.

10）篠田晴男, 國分三輝, 芳賀 繁: 二重課題法によるメンタ ルワークロード要因の心理生理的評価. 人間工学, 34 (1); 37-44, 1998.

11）芳賀 繁，福田康明，高田和之：作業習熟と作業時間が作業 負担に及ぼす影響。日本経営工学会論文誌，49（6）；357-364, 1999.

12) 百瀬直樹 監: 人工心肺操作. 許 俊悦 編. 心臓手術の実際. 初版, 東京, 秀潤社. 2008, p25-29.

13）芳賀 繁：メンタルワークロードの理論と測定. 第 1 版, 東京，日本出版サービス，2001，p13-34.

14）林 博史 編: 心拍変動の臨床応用. 第 1 版, 東京, 医学書院. 2004, p28-36.

15）産業技術総合研究所編：人間計測ハンドブック．第 2 版, 東 京, 朝倉書店. 2004, p82-86.

16）山田晋平，三宅晋司，大須賀美恵子 : 精神疲労を評価する 指標の探索。人間工学，48（6）；295-303，2012.

17）中野敦行, 山口昌樹 : 唾液アミラーゼによるストレス評価. バイオフィードバック研究，38（1）: 4-9, 2011.

18）産業技術総合研究所 編：人間計測ハンドブック．第 2 版, 東京，朝倉書店. 2004, p340-344.

19) Hart SG, Staveland LE: Development of NASA-TLX. Human Mental Workload, North-Holland. 1988. p139-183.

20）芳賀 繁，水上直樹：日本語版 NASA-TLXによるメンタ ルワークロード測定. 人間工学, $32(2): 71-79,1996$.

21）青木和夫：ISO/TC 159 におけるメンタルワークロードの 概念と定義掞よび設計の指針．人間工学，29（6）;339-342, 1993.

22）芳賀 繁：メンタルワークロードの理論と測定. 第 1 版, 東京，日本出版サービス．2001，p105-114.

23）大須賀美恵子, 寺下裕美, 戸田真美子 : ストレス反応の定 量的評価法. 人間工学. 29 (6)；353-356, 1993.

24）河野龍太郎：原子カプラント運転員の精神的作業負荷の諸 問題. 人間工学, 29 (6)；375-375，1993. 